University of Nebraska - Lincoln

DigitalCommons@University of Nebraska - Lincoln

Agronomy \& Horticulture -- Faculty Publications

Agronomy and Horticulture Department

$12-1-2004$

\title{
Agronomic Responses of Corn Hybrids from Different Eras to Deficit and Adequate Levels of Water and Nitrogen
}

\author{
Patrick M. O'Neill \\ University of Nebraska-Lincoln, poneill4@unl.edu \\ J.F. Shanahan \\ University of Nebraska-Lincoln, jshanahan1@unl.edu \\ James S. Schepers \\ University of Nebraska-Lincoln, james.schepers@gmail.com \\ Bob Caldwell \\ University of Nebraska-Lincoln
}

Follow this and additional works at: https://digitalcommons.unl.edu/agronomyfacpub

Part of the Plant Sciences Commons

O'Neill, Patrick M.; Shanahan, J.F.; Schepers, James S.; and Caldwell, Bob, "Agronomic Responses of Corn Hybrids from Different Eras to Deficit and Adequate Levels of Water and Nitrogen" (2004). Agronomy \& Horticulture -- Faculty Publications. 2.

https://digitalcommons.unl.edu/agronomyfacpub/2

This Article is brought to you for free and open access by the Agronomy and Horticulture Department at DigitalCommons@University of Nebraska - Lincoln. It has been accepted for inclusion in Agronomy \& Horticulture -Faculty Publications by an authorized administrator of DigitalCommons@University of Nebraska - Lincoln. 


\title{
CORN
}

\section{Agronomic Responses of Corn Hybrids from Different Eras to Deficit and Adequate Levels of Water and Nitrogen}

\author{
Patrick M. O’Neill, John F. Shanahan,* James S. Schepers, and Bob Caldwell
}

\section{ABSTRACT}

Maintaining current high yields of corn (Zea mays L.) grown in the USA poses an environmental threat due to continued overuse of water and $\mathbf{N}$ inputs. To reduce overreliance on inputs, future corn breeding efforts should focus on improving tolerance of corn to water and $\mathrm{N}$ stresses, utilizing appropriate tolerance mechanisms. The objective of this study was to identify appropriate mechanisms by characterizing agronomic responses of $\mathbf{1 2}$ hybrids from three different eras ('B73 $\times$ Mo17' from 1970s and three early 1990s and eight late 1990s Pioneer brand hybrids) to varying water and $\mathrm{N}$ supply. This was done by growing the hybrids under deficit and adequate levels of water (one-half and full evapotranspiration) and $N\left(0\right.$ and $\left.200 \mathrm{~kg} \mathrm{ha}^{-1}\right)$ in a field study and measuring yield and other agronomic variables. While hybrid eras didn't differ in response to varying water or $\mathbf{N}$, individual hybrids varied in ability to maintain yield under water or N stress. For example, under deficit water, ' 3417 ' produced $27 \%$ more yield than ' 3162 ' while they yielded similarly under adequate water. Likewise, under deficit $\mathrm{N}$, '34R07' produced $42 \%$ more grain yield than '33G27' while they yielded similarly under adequate N. Agronomic variables such as kernel number per unit area were highly correlated with grain yield $(r=0.98)$, indicating hybrid ability to maximize kernel number under varying water and $\mathbf{N}$ supply was critical to maximizing yield. Determining physiological mechanisms associated with ability to maintain kernel number under stress should be a high priority of breeding programs.

$\mathrm{C}$ ORN GROWN UNDER the semiarid conditions of the Great Plains region of the USA requires supplemental irrigation to attain maximum yields (Musick and Dusek, 1980). While irrigation increases corn yields, it depletes groundwater supplies (Clark et al., 2002) and is expensive, with fully irrigated corn requiring 500 to $600 \mathrm{~mm}$ of irrigation water and pumping costs reaching over $\$ 0.20 \mathrm{~mm}^{-1} \mathrm{ha}^{-1}$ in some regions (Norwood and Dumler, 2002). Nitrogen availability represents another major factor limiting corn yields in the Great Plains, requiring the addition of large quantities of $\mathrm{N}$ fertilizers to achieve current high yields (Marschner, 1995). Recent statistics (USDA-NASS, 2003) show for example that corn grown in the USA receives around 5 million tons of $\mathrm{N}$ annually, over 2.5 times the amount applied to wheat

P.M. O'Neill, J.F. Shanahan, and J.S. Schepers, USDA-ARS, Lincoln, NE 68583; and B. Caldwell, Univ. of Nebraska, Lincoln, NE 68583. Joint contribution of USDA-ARS and Agric. Res. Div. of the Univ. of Nebraska. Published as Journal Ser. no. 14623. Mention of commercial products and organizations in this article is solely to provide specific information. It does not constitute endorsement by USDA-ARS over other products and organizations not mentioned. The USDA-ARS is an equal opportunity/affirmative action employer and all agency services are available without discrimination. Received 28 Apr. 2004. *Corresponding author (jshanahan1@unl.edu).

Published in Agron. J. 96:1660-1667 (2004).

(C) American Society of Agronomy

677 S. Segoe Rd., Madison, WI 53711 USA
(Triticum aestivum L.). These high application levels result in low $\mathrm{N}$ use efficiency (NUE), with estimates of NUE for world cereal grain production systems at only $33 \%$ (Raun and Johnson, 1999). This represents a $\$ 15.9$ billion annual loss of fertilizer $\mathrm{N}$. In addition to economic losses, $\mathrm{N}$ overapplication results in environmental contamination through nitrate $\mathrm{N}$ runoff or leaching, making nitrate $\mathrm{N}$ the most common contaminant found in the surface and ground waters of the Corn Belt (CAST, 1999). Thus, while average corn yields have quadrupled over the last $50 \mathrm{yr}$ from the combined use of improved irrigation practices, greater $\mathrm{N}$ fertilizer use, and other technological innovations (Christensen, 2002), maintaining current high yields of corn grown in the Great Plains of the USA poses an environmental threat due to continued overuse of these inputs.

To minimize input costs and environmental damage, farmers will likely have to resort to producing corn with less irrigation water and $\mathrm{N}$ fertilizer in the future. This will lead to increased levels of water and $\mathrm{N}$ stress imposed on the crop. To reduce overreliance on these inputs, future corn breeding efforts should focus on improving tolerance of corn to water and $\mathrm{N}$ stresses, utilizing appropriate stress tolerance mechanisms. Characterizing the agronomic and physiological responses of differing corn hybrids to water and $\mathrm{N}$ stresses could help identify appropriate stress tolerance mechanisms for future corn breeding efforts.

Corn is relatively insensitive to water stress imposed during early vegetative growth stages because water demand is relatively low and plants can adapt to water stress to reduce the impact of subsequent periods of water stress (Shaw, 1977). However, corn grain yield is sensitive to water stress from just before silking though grain fill (Shaw, 1977; Hall et al., 1981; Westgate and Boyer, 1986), with the greatest degree of sensitivity occurring during the period of kernel number determination (Andrade et al., 1999). Hall et al. (1981) indicated that kernel number was most sensitive to stress between tasseling and just after silking.

Nitrogen stress reduces grain yield by delaying plant growth and development (Uhart and Andrade, 1995a) and reducing leaf area index, leaf area duration, and photosynthetic rate (Novoa and Loomis, 1981; Lemcoff and Loomis, 1986; Sinclair and Horie, 1989; Connor et al., 1993). Uhart and Andrade (1995b) also showed that grain yield and kernel number were reduced by $\mathrm{N}$ stress. These results from the literature imply that measurement of agronomic variables like yield components may provide an indication or characterization of hybrid response to stresses.

Abbreviations: NUE, nitrogen use efficiency. 
The role corn breeding efforts have played in increasing average grain yields in the USA over the past $70 \mathrm{yr}$ has been significant, with $60 \%$ of the historic increase attributed to genetic improvement (Duvick, 1992). The genetic improvement has been more specifically ascribed to increased stress tolerance (Duvick, 1992; Tollenaar et al., 1994). A genotype $\times$ environment interaction for grain yield is usually observed when comparing older vs. more recently introduced corn hybrids under multiple environments (Tollenaar and $\mathrm{Wu}, 1999$ ). For example, a previous study by Tollenaar (1989) showed that a newer hybrid was more tolerant of water and $\mathrm{N}$ stress than an older hybrid. Thus, it was hypothesized that more recently developed hybrids would be more tolerant to these stresses than older hybrids. The objective of this study was to identify appropriate stress tolerance mechanisms by characterizing the agronomic responses of hybrids of different eras to varying water and N supply.

\section{MATERIALS AND METHODS}

\section{Experimental Treatments and Field Design}

This experiment was conducted near Shelton, NE $\left(40^{\circ} 45^{\prime} 01^{\prime \prime}\right.$ $\mathrm{N}, 98^{\circ} 46^{\prime} 01^{\prime \prime} \mathrm{W}$; elevation $620 \mathrm{~m}$ above mean sea level), during the growing seasons of 1999 through 2002. The soil at the site is a Hord silt loam (fine-silty, mixed mesic Pachic Haplustolls). The crop was grown under conventional tillage practices following corn with a linear-move sprinkler irrigation system. Climatological data (Fig. 1) were recorded for all growing seasons through the use of an automated weather station (High Plains Climate Center Network, University of Nebraska) located on the research site. Phenology data according to Ritchie et al. (1997) were recorded weekly from the first of June through mid-August.

Treatments consisted of a factorial combination of two water levels (deficit and adequate irrigation), two $\mathrm{N}$ levels ( 0 and $200 \mathrm{~kg} \mathrm{~N} \mathrm{ha}^{-1}$ ), and 12 corn hybrids (11 Pioneer hybrids '3394', '33H67', '3162', '33R87', '33G27', '34K77', '34G82', '34D34', '34R07', '33A14', and '3417' - and the older check hybrid 'B73 $\times$ Mo17'). Hybrids were selected because of their differences in era of release, maturity, and canopy architecture (upright architecture for 3394 vs. planophile orientation for the other hybrids). The hybrid B73 $\times$ Mo17 was included as the older check in this study because it was a popular and widely grown hybrid in Corn Belt region during the 1970s (Troyer, 1999). The experimental design was a strip-split plot design, with water levels as whole plots, $\mathrm{N}$ levels as split plots, and corn hybrids as strip plots with three replications. The same experimental design, regarding plot randomization for all experimental units, was used in each year of the study to minimize water and $\mathrm{N}$ treatment carryover effects from one year to the next. Hybrid characteristics are given in Table 1. Individual plot dimensions were $30.5 \mathrm{~m}$ long by $3.7 \mathrm{~m}$ wide, consisting of four rows spaced at $0.925 \mathrm{~m}$, a row spacing commonly used in this region. Each hybrid was seeded at a density of 81500 plants ha ${ }^{-1}$. Liquid starter fertilizer (10-34-0) was applied at the rate of $94 \mathrm{~L} \mathrm{ha}^{-1}$ in the furrow at planting, providing approximately $18 \mathrm{~kg} \mathrm{ha}^{-1}$ of $\mathrm{P}$. Weed control was accomplished through a combination of cultivation and herbicide application. Pests were controlled with pesticide applications as needed. At V6 growth stage, $200 \mathrm{~kg} \mathrm{ha}^{-1}$ of $\mathrm{N}$ was sidedressed as anhydrous ammonia on the adequate $\mathrm{N}$ plots.

Water treatments (deficit and adequate irrigation) were initiated during late vegetative growth stage (around V9).
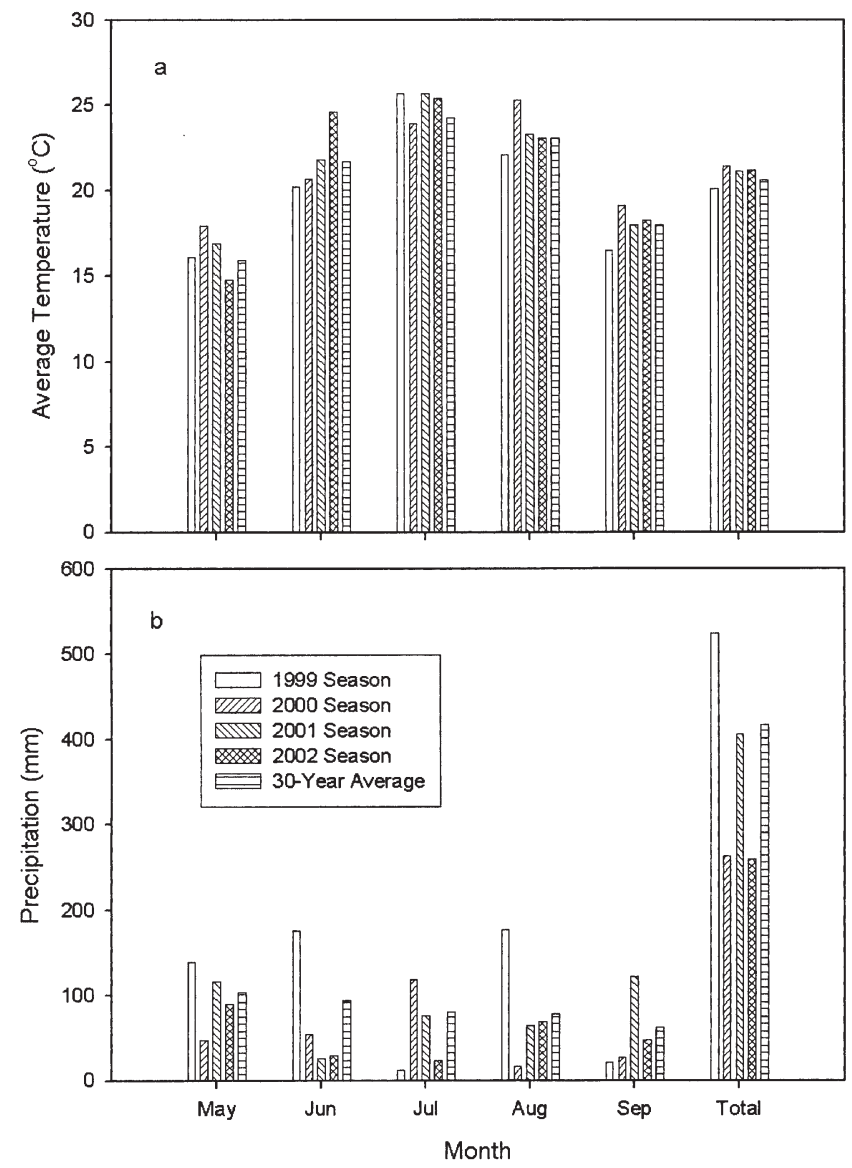

Fig. 1. Monthly average (a) temperature and (b) precipitation for the 1999-2002 growing seasons calculated from measurements gathered by an automated weather station (High Plains Climate Center Network, University of Nebraska) located at Shelton, NE. For comparison purposes, 30-yr averages of (a) temperature and (b) precipitation of the surrounding area are also presented.

Beginning on these dates, water was applied at weekly intervals based on the amount of evapotranspiration for the previous week as determined by the on-site weather station using a modified version of the Penman equation (Kincaid and Heerman, 1974). The adequate irrigation treatment received the amount of water required to fully replace the previous week evapotranspiration while the deficit treatment received approximately one-half this amount. This was continued throughout the remainder of the growing season.

Table 1. Era and year of introduction and growing days until harvest (CRM) for 12 corn hybrids grown during the 1999-2002 growing seasons at Shelton, $\mathrm{NE}$.

\begin{tabular}{lcc}
\hline Hybrid & $\begin{array}{c}\text { Era and year } \\
\text { of introduction }\end{array}$ & CRM \\
\hline B73 $\times$ MO17 & $\begin{array}{c}1970 s \\
\text { Early 1990s }\end{array}$ & 118 \\
Pioneer brand hybrids & 1989 & 118 \\
3162 & 1990 & 109 \\
3417 & 1991 & 110 \\
3394 & Late 1990s & 113 \\
33 314 & 1997 & 112 \\
33H67 & 1998 & 113 \\
33G27 & 1999 & 113 \\
33R87 & 1999 & 108 \\
34G82 & 1999 & 110 \\
34K77 & 1999 & 110 \\
34D34 & 1999 & \\
34R07 & 1999 & \\
\hline
\end{tabular}




\section{Harvest Procedures and Statistical Analysis}

At physiological maturity, plants from a 3.1-m section of row within the center two rows of each plot were harvested to determine total biomass yield. The ears were removed from the plants and the stalks chopped and weighed. A subsample of stover biomass was collected and oven-dried for $48 \mathrm{~h}$ at $40^{\circ} \mathrm{C}$ to adjust stover biomass yields to $0 \mathrm{~g} \mathrm{~kg}^{-1}$ water. The harvested ears were oven-dried for $48 \mathrm{~h}$ at $40^{\circ} \mathrm{C}$ and weighed to determine ear mass at $0 \mathrm{~g} \mathrm{~kg}^{-1}$ water. Total plot biomass was calculated from the sum of stover and ear weights. Ears were shelled and total grain weight determined. A subsample of 100 kernels was used to determine mass per kernel. After plot biomass sampling, the center two rows of the entire length $(30.5 \mathrm{~m})$ of each plot were machine-harvested. A subsample of machine-harvested grain was collected and moisture content determined using a Burrows digital moisture meter (model 700, Seedburrow Equipment Co., Chicago, IL), and yield adjusted to $0 \mathrm{~g} \mathrm{~kg}^{-1}$ water. Total grain yield for each plot was determined by summing hand- and machine-harvested grain samples. Kernel numbers per unit area for each plot were determined by calculation using plot grain yield per unit area and kernel weight estimates from hand-harvest samples.

To determine $\mathrm{N}$ concentrations of grain and stover, grain and stover subsamples were first processed with a Stein mill and then a Wiley mill (20-mesh sieve). A subsample of approximately $0.3 \mathrm{~g}$ of the processed stover and $1.5 \mathrm{~g}$ of the processed grain was further ground on a roller mill as per Arnold and Schepers (2004). Approximately $5.5 \mathrm{mg}$ of the roller-milled stover and grain subsamples were used to determine $\mathrm{N}$ concentration using a Carlo Erba flash combustion $\mathrm{N}$ analyzer, Model 1500 Series 2 (Carlo Erba Instruments, Milan, Italy). The analyzer was calibrated periodically using standards withknown $\mathrm{N}$ concentration. Total $\mathrm{N}$ uptake per plot was determined by multiplying $\mathrm{N}$ concentration for the stover and grain samples times their respective weights and summing the two values.

Yield response to applied $\mathrm{N}$ was calculated for each unique hybrid and water treatment combination as:

$$
\begin{aligned}
& \mathrm{N} \text { response }(\%)= \\
& \frac{\text { Adequate } \mathrm{N} \text { yield }- \text { Deficit N yield }}{\text { Deficit } \mathrm{N} \text { yield }} \times 100 \%
\end{aligned}
$$

Yield response to adequate water was calculated in a similar fashion. Fertilizer use efficiency (FUE) was calculated as:
FUE $(\%)=$

$\frac{\left(\mathrm{N} \text { uptake under } 200 \mathrm{~kg} \mathrm{~N} \mathrm{ha}^{-1}\right)-\left(\mathrm{N}^{-1} \text { uptake under } 0 \mathrm{~kg} \mathrm{~N}^{-1}\right)}{200 \mathrm{~kg} \mathrm{~N} \mathrm{ha}^{-1}} \times 100 \%$

Grain NUE was calculated as:

$$
\mathrm{NUE}=\frac{\mathrm{Mg} \text { dry grain ha }}{\text { hg }} \mathrm{N}_{\text {uptake } \mathrm{ha}^{-1}}
$$

Analyses of variance for the various agronomic variables were performed using SAS PROC MIXED (Littel et al.,1996) with the Kenward-Roger degrees-of-freedom method. This method uses an adjusted estimator of the covariance matrix to reduce small sample bias (Kenward and Roger, 1997). Water, N, and hybrid were treated as fixed effects and year and replication as random effects. One ANOVA was calculated with corn hybrids grouped by era of introduction (Table 2), and a second ANOVA was calculated without era grouping of hybrids (Table 3). Treatment means were compared by LSD and calculated using SAS PROC GLM. Associations between grain yield and the other agronomic variables were determined with genotypic correlations, using hybrid treatment means for each year.

\section{RESULTS AND DISCUSSION Climatological Conditions}

Climatological measurements for the four growing seasons are shown in Fig. 1. While fluctuations in monthly temperatures were observed from year to year, average seasonal temperatures for each of the $4 \mathrm{yr}$ were comparable and similar to the long-term average for this location. On the other hand, seasonal precipitation was slightly more variable among the 4 yr, with the 1999 season receiving $25 \%$ more precipitation than the longterm average while the other $3 \mathrm{yr}$ received either average or below-average precipitation.

\section{Water and Nitrogen Effects on Grain Yields}

Although seasonal precipitation varied slightly among the $4 \mathrm{yr}$, there was a consistent effect of the water treatment on grain yields (Table 2), with an average yield increase of around $23 \%$ associated with adequate vs. deficit water levels (Fig. 2). Likewise, $\mathrm{N}$ application affected grain yields as well, with an average yield increase of around $100 \%$ associated with adequate vs. deficit $\mathrm{N}$

Table 2. Analysis of variance for grain yield, total dry matter (DM), kernel weight (KW), kernels per hectare (KN), total $\mathbf{N}$ uptake per hectare (NUP), N use efficiency (NUE), and fertilizer use efficiency (FUE) from 12 corn hybrids representing three eras of introduction

\begin{tabular}{|c|c|c|c|c|c|c|c|c|}
\hline \multirow[b]{2}{*}{ Source of variation } & \multirow[b]{2}{*}{ df } & \multicolumn{7}{|c|}{ Agronomic variables } \\
\hline & & Yield & DM & KW & $\mathbf{K N}$ & NUP & NUE & FUE \\
\hline Water (W) & 1 & ** & $*$ & $\mathbf{N S} \dagger$ & ** & NS & $\ddagger$ & $\ddagger$ \\
\hline $\mathbf{N}$ & 1 & ** & $* *$ & $\ddagger$ & $* *$ & $* *$ & $* *$ & \\
\hline Hybrid era (E) & 2 & NS & NS & NS & NS & $* *$ & NS & $*$ \\
\hline $\mathbf{W} \times \mathbf{N}$ & 1 & $\neq$ & NS & NS & NS & NS & NS & \\
\hline $\mathbf{W} \times \mathbf{E}$ & 2 & NS & NS & NS & 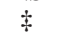 & NS & NS & $\ddagger$ \\
\hline $\mathbf{N} \times \mathbf{E}$ & 2 & $*$ & NS & NS & $*$ & $* *$ & NS & \\
\hline $\mathbf{W} \times \mathbf{N} \times \mathbf{E}$ & 2 & NS & NS & NS & NS & NS & NS & \\
\hline
\end{tabular}
exposed to two water levels (deficit and adequate) and two $\mathrm{N}$ levels $\left(0\right.$ and $200 \mathrm{~kg} \mathrm{~N} \mathrm{ha}^{-1}$ ) during the $1999-2002$ growing seasons at Shelton, NE.

* Significant at the 0.05 probability level.

** Significant at the 0.01 probability level.

$\dagger$ NS, nonsignificant.

$\$$ Significant at the $\mathbf{0 . 1 0}$ probability level. 
Table 3. Analysis of variance for grain yield, total dry matter (DM), kernel weight (KW), kernels per hectare (KN), total N uptake per hectare (NUP), $\mathbf{N}$ use efficiency (NUE), and fertilizer use efficiency (FUE) from 12 corn hybrids exposed to two water levels (deficit and adequate) and two $\mathrm{N}$ levels $\left(0\right.$ and $\left.200 \mathrm{~kg} \mathrm{~N} \mathrm{ha}^{-1}\right)$ during the 1999-2002 growing seasons at Shelton, NE.

\begin{tabular}{|c|c|c|c|c|c|c|c|c|}
\hline \multirow[b]{2}{*}{ Source of variation } & \multirow[b]{2}{*}{ df } & \multicolumn{7}{|c|}{ Agronomic variables } \\
\hline & & Yield & DM & KW & KN & NUP & NUE & FUE \\
\hline Water (W) & 1 & ** & $*$ & $\mathbf{N S} \dagger$ & $* *$ & $\dagger$ & $\ddagger$ & $\ddagger$ \\
\hline $\mathbf{N}$ & 1 & $* *$ & $* *$ & $\ddagger$ & ** & ** & $* *$ & \\
\hline Hybrid (H) & 11 & $* *$ & $* *$ & $* *$ & $* *$ & ** & ** & $* *$ \\
\hline $\mathbf{W} \times \mathbf{N}$ & 1 & $\ddagger$ & NS & NS & NS & NS & NS & \\
\hline $\mathbf{W} \times \mathbf{H}$ & 11 & $* *$ & $\ddagger$ & $\ddagger$ & $* *$ & $* *$ & $* *$ & NS \\
\hline $\mathbf{N} \times \mathbf{H}$ & 11 & $* *$ & $* *$ & $* *$ & $* *$ & $* *$ & $* *$ & \\
\hline $\mathbf{W} \times \mathbf{N} \times \mathbf{H}$ & 11 & NS & NS & NS & NS & NS & NS & \\
\hline
\end{tabular}

* Significant at the 0.05 probability level.

** Significant at the 0.01 probability level.

$\dagger$ NS, nonsignificant.

+ Significant at the 0.10 probability level.

levels. The water $\times \mathrm{N}$ interaction term was also significant and was due to a greater yield response for $\mathrm{N}$ application under adequate water conditions vs. lower yield response to $\mathrm{N}$ under deficit water conditions (Fig. 2). These results are consistent with previous work (Pandey et al., 2000) and illustrate the additive effect that water and $\mathrm{N}$ inputs have on maximizing corn productivity. In summary, the imposed water and $\mathrm{N}$ treatments used in this study provided consistent differences in crop water and $\mathrm{N}$ status across years to successfully address the study objective of evaluating hybrid agronomic responses to varying water and $\mathrm{N}$ levels.

\section{Hybrid Response to Varying Water and Nitrogen Levels}

To evaluate hybrid responses to varying water and $\mathrm{N}$ levels, the ANOVA was done first (Table 2) with hybrids grouped into three eras of introduction (Table 1) and then with the hybrids considered individually (Table 3). To test the hypothesis of whether newer hybrids are more tolerant than older hybrids to water or $\mathrm{N}$ stress, the interaction terms of era $X$ water and era $X$ $\mathrm{N}$ were considered the main criterion for determining whether there was a differential era response to varying water or $\mathrm{N}$ supply. Additionally, other interaction terms involving era were also evaluated in an attempt to better understand era responses. The water $\times \mathrm{N} \times$ era interaction term was not significant, indicating that era response to water and $\mathrm{N}$ was independent of the other treatment factor. Thus, evaluation of the era responses to water and $\mathrm{N}$ independently was considered to be a valid means for expressing the differential era response to varying water or $\mathrm{N}$ supply.

Comparing the era $\times$ water and era $\times \mathrm{N}$ interaction terms (Table 2), it is clear that eras responded differently only to varying $\mathrm{N}$ levels and not to varying water levels. This is further illustrated by comparing average yields for the three eras grown under both deficit and adequate levels of water and N (Table 4), with the three hybrid eras producing comparable yields under deficit and adequate water. While the three eras produced similar yields under deficit N, the early- and late-1990s hybrids yielded more then the 1970s hybrid under adequate $\mathrm{N}$ conditions, indicating a greater yield response to $\mathrm{N}$ application. For example, the 1970s hybrid exhib- ited a $73 \%$ increase in yield in response to $\mathrm{N}$ application while the early- and late-1990s hybrids produced 102 and $111 \%$ increases, respectively (Table 4 ). These results imply that the differential era response to $\mathrm{N}$ was not due to era differences in $\mathrm{N}$ stress tolerance but rather to era differences in ability to respond to $\mathrm{N}$ application, with newer hybrids exhibiting greater yield responses than older hybrids. Collectively, these results do not support our initial hypothesis regarding increased tolerance to water and $\mathrm{N}$ stresses for newer vs. older hybrids and are contrary to the results of Tollenaar and $\mathrm{Wu}$ (1999), who suggested that newer hybrids possess greater stress tolerance than older hybrids. However, it should be noted that the range in age of hybrid eras used in our work was only around $20 \mathrm{yr}$ compared with around $30 \mathrm{yr}$ for the hybrids studied by Tollenaar and $\mathrm{Wu}$ (1999). Hence, the work by the previous authors likely represents a better estimate of progress in genetic gain in stress tolerance associated with corn breeding efforts over time.

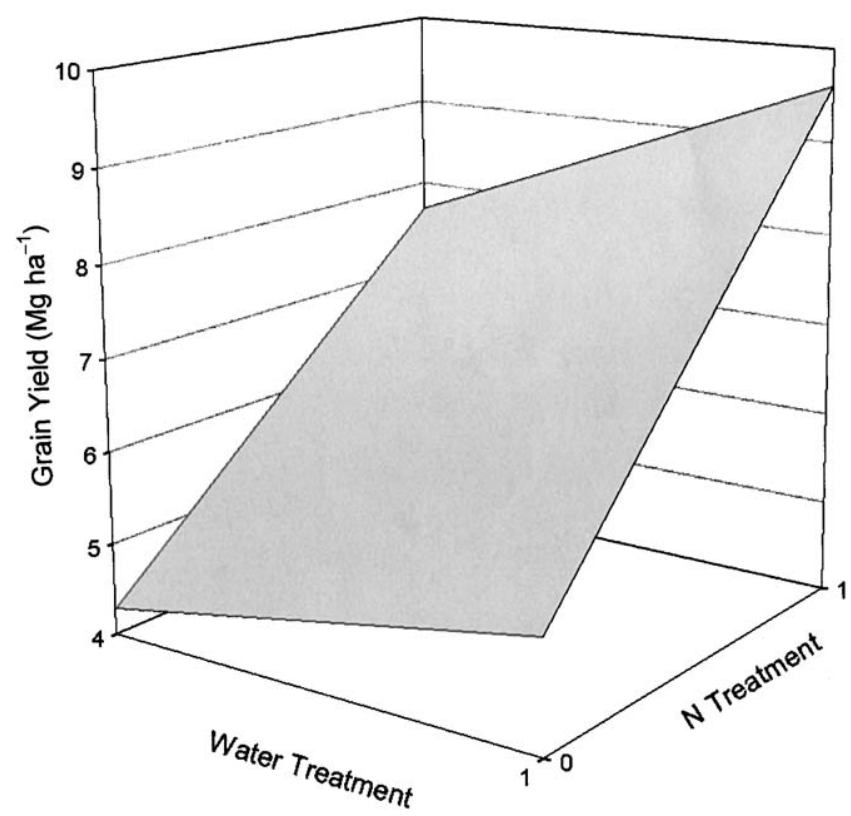

Fig. 2. Mean grain yield for 12 hybrids under a factorial combination of two water treatments $(0=$ deficit and $1=$ adequate $)$ and two $\mathrm{N}$ treatments $(0=$ deficit and $1=$ adequate $)$ averaged over $4 \mathrm{yr}$ (1999-2002) at Shelton, NE. 
Table 4. Mean grain yield and yield response to water and $\mathrm{N}$ for 12 corn hybrids representing three eras of introduction. Means represent averages across four growing seasons (1999-2002) at Shelton, NE.

\begin{tabular}{|c|c|c|c|c|c|c|c|}
\hline \multirow[b]{2}{*}{ Hybrid } & \multirow[b]{2}{*}{ Era } & \multicolumn{3}{|c|}{ Water treatment } & \multicolumn{3}{|c|}{$\mathrm{N}$ treatment } \\
\hline & & Deficit & Adequate & Response & Deficit & Adequate & Response \\
\hline & & \multicolumn{2}{|c|}{$\longrightarrow \mathrm{Mg} \mathrm{ha}^{-1}$} & $\%$ & \multicolumn{2}{|c|}{$\longrightarrow \mathrm{Mg} \mathrm{ha}^{-1}$} & $\%$ \\
\hline B73 $\times$ Mo17 & 1970s & $6.10 \mathrm{a} \dagger$ & 7.20 a & 24 a & $5.02 \mathrm{a}$ & $8.23 \mathrm{c}$ & 73 b \\
\hline 3162 & early $1990 \mathrm{~s}$ & 5.30 & 7.61 & 50 & 4.33 & 8.67 & 123 \\
\hline 3394 & & 5.61 & 6.73 & 23 & 4.44 & 7.90 & 86 \\
\hline \multirow[t]{2}{*}{3417} & & 6.75 & 7.93 & 21 & 5.09 & 9.58 & 97 \\
\hline & era average & $5.90 \mathrm{a}$ & $7.45 \mathrm{a}$ & 31 a & $4.62 \mathrm{a}$ & $8.72 \mathrm{~b}$ & 102 a \\
\hline 33A14 & late $1990 \mathrm{~s}$ & 6.19 & 8.09 & 35 & 5.10 & 9.18 & 90 \\
\hline 33G27 & & 5.77 & 6.98 & 21 & 3.93 & 8.82 & 150 \\
\hline 33H67 & & 5.98 & 7.63 & 29 & 4.46 & 9.15 & 120 \\
\hline 33R87 & & 6.25 & 7.93 & 28 & 4.49 & 9.69 & 126 \\
\hline $34 D 34$ & & 6.32 & 7.64 & 24 & 4.55 & 9.41 & 123 \\
\hline $34 G 82$ & & 5.76 & 6.98 & 21 & 4.15 & 8.59 & 117 \\
\hline 34K77 & & 6.31 & 7.68 & 25 & 4.86 & 9.13 & 95 \\
\hline \multirow[t]{3}{*}{ 34R07 } & & 6.52 & 8.18 & 29 & 5.60 & 9.10 & 66 \\
\hline & era average & $6.14 \mathrm{a}$ & $7.62 \mathrm{a}$ & 27 a & $4.64 \mathrm{a}$ & $9.13 \mathrm{a}$ & 111 a \\
\hline & hybrid LSD & 0.57 & 0.56 & 16 & 0.58 & 0.56 & 21 \\
\hline
\end{tabular}

$\dagger$ Era means within a column and having the same letter are not significantly different $(0.05)$.

Even though hybrid eras in our study did not respond differently to varying water levels, individual hybrids did, as shown by the significant water $\times$ hybrid interaction (Table 3). This is best illustrated by comparing yields of hybrids 3162 and 3417 under deficit and adequate water (Table 4). Under deficit water, 3417 produced $27 \%$ more grain yield than 3162 , with the other hybrids yielding between these two extremes, while under adequate water, the same two yielded similarly. This resulted in hybrid 3162 exhibiting a more pronounced yield response than 3417 to additional water, with the former showing a $50 \%$ increase, the latter only a $21 \%$ increase, and the other hybrids ranging between these two extremes. Individual hybrids also responded differently to varying $\mathrm{N}$ levels (Table 3 ), as seen by the significant $\mathrm{N} \times$ hybrid interaction (Table 3 ). This is best demonstrated by comparing the yields of hybrids $34 \mathrm{R} 07$ and 33G27 under deficit and adequate $\mathrm{N}$ (Table 4). Under deficit N, 34R07 produced $42 \%$ more grain yield than the lowest-yielding hybrid 33G27, with the other hybrids yielding between these two extremes (Table 4). With adequate $\mathrm{N}$, these same two hybrids produced similar yields. This resulted in hybrid 33G27 exhibiting a greater yield response to additional $\mathrm{N}$ than $34 \mathrm{R} 07$, with the former showing a $150 \%$ increase and the latter only a $66 \%$ increase. The ANOVA for fertilizer use efficiency values for the hybrids also revealed that hybrids responded differently to additional $\mathrm{N}$ fertilizer (Table 3 ), with newer hybrids producing more grain per unit of additional $\mathrm{N}$ fertilizer (Table 5), and this was especially true under adequate water conditions.

While the hybrids grouped by era of introduction did not vary in their ability to tolerate water or $\mathrm{N}$ stress, the individual hybrids did vary in their ability to maintain yields under these stresses. Likewise, they varied in their ability to respond to adequate water and $\mathrm{N}$ conditions, maximizing yields. To determine the associations between hybrid performance under deficit and adequate levels of water and N (Table 6), linear correlation analysis was conducted using mean yields of the hybrids grown under both levels of water and N (Table 5). This analysis revealed that hybrid yield variation was more highly associated for the deficit water vs. deficit $\mathrm{N}$ levels $(r=$ $0.72, P \leq 0.01)$ than for deficit water vs. adequate water levels $(r=0.65, P \leq 0.05)$. Similarly, hybrid yield variation was more highly associated for adequate $\mathrm{N}$ vs. adequate water levels $(r=0.78, P \leq 0.01)$ than for adequate vs. deficit $\mathrm{N}$ levels $(r=0.24$, NS). Thus, variation in

Table 5. Mean fertilizer use efficiency (FUE) and grain N use efficiency (NUE) for 12 corn hybrids representing three eras of introduction. Means represent averages across four growing seasons (1999-2002) at Shelton, NE.

\begin{tabular}{|c|c|c|c|c|c|c|c|}
\hline \multirow[b]{2}{*}{ Hybrid } & \multirow[b]{2}{*}{ Era } & \multicolumn{2}{|c|}{ FUE } & \multicolumn{4}{|c|}{ NUE } \\
\hline & & Deficit water & Adequate water & Deficit water & Adequate water & Deficit $\mathbf{N}$ & Adequate N \\
\hline & & \multicolumn{2}{|c|}{$\longrightarrow \mathrm{Mg} \mathrm{Mg}^{-1}$} & \multicolumn{4}{|c|}{$\mathbf{M g ~ M g}^{-1}$} \\
\hline B73 $\times$ Mo17 & $1970 \mathrm{~s}$ & $41 \mathrm{~b} \dagger$ & $44 \mathrm{c}$ & 55 a & 57 a & $62 \mathrm{a}$ & 50 a \\
\hline 3162 & early 1990s & 44 & 56 & 49 & 54 & 55 & 48 \\
\hline 3394 & & 39 & 49 & 53 & 57 & 61 & 49 \\
\hline \multirow[t]{2}{*}{3417} & & 47 & 54 & 60 & 62 & 68 & 54 \\
\hline & average & 43 b & 53 b & 54 a & 58 a & 61 a & 50 a \\
\hline 33A14 & late 1990s & 47 & 55 & 57 & 60 & 66 & 51 \\
\hline 33G27 & & 54 & 70 & 46 & 49 & 52 & 44 \\
\hline 33H67 & & 48 & 60 & 50 & 60 & 60 & 50 \\
\hline 33R87 & & 60 & 65 & 52 & 56 & 59 & 48 \\
\hline $34 D 34$ & & 60 & 63 & 51 & 54 & 58 & 47 \\
\hline 34G82 & & 52 & 61 & 52 & 53 & 58 & 47 \\
\hline $34 K 77$ & & 52 & 63 & 56 & 57 & 65 & 48 \\
\hline \multirow[t]{3}{*}{ 34R07 } & & 44 & 53 & 55 & 63 & 68 & 50 \\
\hline & average & 52 a & $61 \mathrm{a}$ & 52 a & 57 a & $61 \mathrm{a}$ & 48 b \\
\hline & hybrid LSD & 11 & 10 & 3 & 3 & 3 & 3 \\
\hline
\end{tabular}

$\dagger$ Era means within a column and having the same letter are not significantly different $(0.05)$. 
Table 6. Genotypic correlations of hybrid mean yields grown under deficit and adequate water and $\mathbf{N}$ conditions.

\begin{tabular}{|c|c|c|c|c|}
\hline & $\begin{array}{l}\text { Deficit } \\
\text { water }\end{array}$ & $\begin{array}{c}\text { Adequate } \\
\text { water }\end{array}$ & Deficit N & Adequate $\mathbf{N}$ \\
\hline Deficit water & 1.000 & & & \\
\hline Adequate water & $0.655^{*}$ & 1.000 & & \\
\hline Deficit $\mathbf{N}$ & $0.715 * *$ & $0.679 *$ & 1.000 & \\
\hline Adequate N & $0.676^{*}$ & $0.789 * *$ & 0.242 & 1.000 \\
\hline
\end{tabular}

* Significant at the 0.05 probability level.

** Significant at the 0.01 probability level.

hybrid performance under deficit water was better predicted by hybrid performance under deficit $\mathrm{N}$ than under adequate water conditions, which is consistent with observations of Bänziger et al. (2002), who observed a low correlation between corn genotype performance under deficit and well-fertilized $\mathrm{N}$ conditions. The likely explanation for these observations is that the water and $\mathrm{N}$ stresses imposed on the hybrids produced similar adverse effects on key physiological processes, as suggested by Andrade et al. (2002), with both stresses having similar negative impacts on grain yield. For example, Bänziger et al. (2002) found that genotypes selected for drought tolerance also possessed physiological mechanisms conferring tolerance to $\mathrm{N}$ stress, with tolerant genotypes maintaining yields under both stresses relative to susceptible genotypes. It should also be noted that while the stress tolerant hybrids like 3417 and 34R07 maintained yields under water or $\mathrm{N}$ stress relative to more susceptible hybrids, they also produced yields similar to the highest-yielding hybrid 3162 under adequate levels of both inputs (Table 4). Thus, physiological mechanisms conferring water and $\mathrm{N}$ stress tolerance, apparently possessed by 3417 and 34R07, did not limit yields under optimal conditions. These results suggest that combining stress tolerance along with high yield potential should be feasible for future corn breeding efforts.

\section{Associations between Grain Yield and other Agronomic Variables}

Corn grain yield is closely linked with kernel number at maturity, with kernel number being determined by the physiological status of the crop around flowering (Kiniry and Ritchie, 1985; Otegui and Andrade, 2000). The importance of kernel number to grain yield was also noted in this study, as seen by the strong association between treatment (water, $\mathrm{N}$, and hybrids)-induced variability in grain yield and kernel number per unit area (Table 7). Thus, hybrids' possessing physiological mech-

Table 7. Genotypic correlation values for associations among grain yield, total dry matter (DM), kernel weight (KW), number of kernels per hectare (KN), $\mathbf{N}$ uptake (NUP), and $\mathbf{N}$ use efficiency (NUE) collected from 12 corn hybrids grown under two water levels and two N levels during the 1999-2002 growing seasons at Shelton, NE.

\begin{tabular}{|c|c|c|c|c|c|c|}
\hline & Yield & DM & KW & KN & NUP & NUE \\
\hline Yield & 1.000 & & & & & \\
\hline DM & $0.975 * *$ & 1.000 & & & & \\
\hline KW & $\mathbf{0 . 8 3 3} * *$ & $0.813 * *$ & 1.000 & & & \\
\hline KN & $0.985 * *$ & $0.958 * *$ & $0.730 * *$ & 1.000 & & \\
\hline NUP & $0.966 * *$ & $0.956 * *$ & $0.807 * *$ & $0.955 * *$ & 1.000 & \\
\hline NUE & $-0.548 * *$ & $-0.581 * *$ & $-0.460 *$ & $-0.545^{* *}$ & $-0.733 * *$ & 1.0 \\
\hline
\end{tabular}

* Significant at the 0.05 probability level.

** Significant at the 0.01 probability level. anisms conferring the ability to maximize kernel number under deficit and adequate levels of both water and $\mathrm{N}$ was critical to their ability to maximize grain yields. According to Andrade et al. (2002) and Bänziger et al. (2002), crop stresses imposed during flowering, regardless of whether induced by water, $\mathrm{N}$ or light, have similar adverse effects on the physiological status of the crop through diminished photosynthetic rates, assimilate supplies, and plant growth rates. This in turn adversely affects the capacity of the corn plant to set kernels during critical reproductive growth stages, with kernel number and ultimately grain yield being negatively impacted by these stresses. Corn is thought to be more susceptible to stresses at flowering than many crops because of the large distance between male and female organs, exposing pollen and fragile stigmatic tissue to desiccating conditions during pollination (Bänziger et al., 2000). Finally, silk growth and kernel number determination are extremely sensitive to the availability of photosynthetic products during flowering (Schussler and Westgate, 1995). Studies comparing the response of stress-tolerant hybrids with sensitive hybrids have found different relationships between kernel number and crop physiological status (Tollenaar et al., 1992), with stress-tolerant hybrids setting more grains than susceptible hybrids under similar levels of crop stress.

As previously stated, the ability to maintain photosynthesis and assimilate supply under water and $\mathrm{N}$ stresses during flowering is crucial for maintaining seed number and grain yield. The role crop $\mathrm{N}$ status plays in maintaining photosynthesis has been well documented (Wolfe et al., 1988; Uhart and Andrade, 1995b; Settimi and Maranville, 1998), with previous research showing about $50 \%$ of all leaf $\mathrm{N}$ being directly involved in photosynthesis either as enzymes or as chlorophyll. Because of the physiological link between crop N status and photosynthesis, $\mathrm{N}$ uptake, crop biomass production, kernel number, and grain yield are all typically strongly correlated, as was confirmed in our work (Table 7). Thus, the ability of hybrids to maximize $\mathrm{N}$ uptake under deficit and adequate levels of $\mathrm{N}$ was critical to their ability to maximize kernel number, as seen by the strong association between $\mathrm{N}$ uptake and kernel number (Table 7), and consequently grain yields were maximized. According to Bänziger et al. (2000), maintenance of grain yield under $\mathrm{N}$ stress is obtained by maximizing both $\mathrm{N}$ uptake and NUE. They observed NUE values of 30 to $70 \mathrm{~kg}$ grain per $\mathrm{kg} \mathrm{N}$ at low levels of $\mathrm{N}$ availability, which is similar to the values observed in this study for the 12 hybrids grown under deficit $\mathrm{N}$ (Table 5). Under adequate $\mathrm{N}$ levels, NUE decreased by an average of $12 \%$ for the 12 hybrids relative to deficit $\mathrm{N}$ conditions (Table 5), indicating $\mathrm{N}$ assimilated into the plant was used less efficiently under increasing $\mathrm{N}$ availability. These results are consistent with the observations of Bänziger et al. (2000). The association between hybrid variation in grain yield and NUE can be further understood by examining the correlation between hybrid values for NUE and grain yield under all levels of water and $\mathrm{N}$ where it was observed to be negatively correlated (Table 7). However, when the correlation analysis was done (data 
not shown) using hybrid values for only deficit $\mathrm{N}$ treatments, then the correlation was positive $(r=0.79, P \leq$ 0.01 ). Thus, across a wide range of available $\mathrm{N}$, hybrid variability in NUE and grain yield appears to be negatively associated while under low-N conditions, the association is positive. These results suggest that selection of potential new hybrids should occur under limited soil $\mathrm{N}$, if the goal is to develop hybrids with increased NUE and ability to maintain grain yield under $\mathrm{N}$ stress, which agrees with the recommendation of Bänziger et al. (2000).

\section{SUMMARY AND CONCLUSIONS}

Twelve corn hybrids from three eras of release (1970s and early 1990s and late 1990s) were grown under deficit and adequate levels of water and $\mathrm{N}$ to characterize their agronomic responses to varying water and $\mathrm{N}$ supply. While hybrid eras did not differ, individual hybrids varied in their ability to maintain yields under water or $\mathrm{N}$ stress. Likewise, they varied in their ability to respond to adequate water and $\mathrm{N}$ conditions, maximizing yields. Some hybrids were observed to yield relatively well under both deficit and adequate conditions of water or N, suggesting that it should be feasible to combine stress tolerance along with high yield potential in future elite germplasm.

Kernel number was highly associated with grain yield ( $r=0.98)$, indicating that possessing physiological mechanisms conferring ability to maximize kernel number under deficit and adequate levels of both water and $\mathrm{N}$ was critical for hybrids to maximize grain yields. Thus, determining physiological mechanisms associated with ability to maintain kernel number under water and $\mathrm{N}$ stress should be a high priority of corn improvement programs. Previous research has shown that kernel number is strongly linked to assimilate supply during the critical period around flowering, which is in turn determined by ability to maintain photosynthetic rate under stress during this time. Perhaps measurements of leaf photosynthetic rates of differing genotypes grown under water or $\mathrm{N}$ stress during this critical time period could provide additional insights regarding stress tolerance mechanisms.

\section{ACKNOWLEDGMENTS}

We thank Pioneer Hi-Bred International of Johnston, IA, for donation of seed used in this study.

\section{REFERENCES}

Andrade, F.H., L. Echarte, R. Rizzalli, A. Della Maggiora, and M. Casanovas. 2002. Kernel number prediction in maize under nitrogen or water stress. Crop Sci. 42:1173-1179.

Andrade, F.H., C.R. Vega, S.A. Uhart, A.G. Cirilo, M. Cantarero, and O. Valentinuz. 1999. Kernel number determination in maize. Crop Sci. 39:453-459.

Arnold, S.L., and J.S. Schepers. 2004. A simple roller-mill grinding procedure for plant and soil samples. Commun. Soil Sci. Plant Anal. 35:537-545.

Bänziger, M., G.O. Edmeades, D. Beck, and M. Bellon. 2000. Breeding for drought and nitrogen stress tolerance in maize: From theory to practice. CIMMYT, Mexico D.F., Mexico.

Bänziger, M., G.O. Edmeades, and H.R. Lafitte. 2002. Physiological mechanisms contributing to the increased $\mathrm{N}$ stress tolerance of tropical maize selected for drought tolerance. Field Crops Res. 75:223-233.

[CAST] Council for Agricultural Science and Technology. 1999. Gulf of Mexico hypoxia: Land and sea interactions. Task Force Rep. 134. CAST, Ames, IA.

Christensen, L.A. 2002. Soil, nutrient, and water management systems used in U.S. corn production [Online]. Available at www.ers.usda. gov/publications/aib774/ (verified 20 Aug. 2004). Agric. Info. Bull. 774. USDA Econ. Res. Serv., Washington, DC.

Clark, J.S., E.C. Grimm, J.J. Donocan, S.C. Fritz, D.R. Engstrom, and J.E. Almendinger. 2002. Drought cycles and landscape responses to past aridity on prairies of the Northern Great Plains, USA. Ecology 83:595-601.

Connor, D.J., A.J. Hall, and V.O. Sadras. 1993. Effect of nitrogen content on the photosynthetic characteristics of sunflower leaves. Aust. J. Plant Physiol. 20:251-263.

Duvick, D.N. 1992. Genetic contributions to yield gains of U.S. hybrid maize, 1930 to 1980. Maydica 37:69-79.

Hall, A.J., J.H. Lemcoff, and N. Trapani. 1981. Water stress before and during flowering in maize and its effects on yield, its components, and their determinants. Maydica 26:19-38.

Kenward, M.G., and J.H. Roger. 1997. Small sample inference for fixed effects from restricted maximum likelihood. Biometrics 53:983-997.

Kincaid, D.C., and D.F. Heerman. 1974. Scheduling irrigations using a programmable calculator. USDA-ARS, Washington, DC.

Kiniry, J.R., and J.T. Ritchie. 1985. Shade-sensitive interval of kernel number of maize. Agron. J. 77:711-715.

Lemcoff, J.H., and R.S. Loomis. 1986. Nitrogen influences on yield determination in maize. Crop Sci. 26:1017-1022.

Littel, R.C., G.A. Miliken, W.W. Stroup, and R.D. Wolfinger. 1996. SAS systems for mixed models. SAS Inst., Cary, NC.

Marschner, H. 1995. Mineral nutrition of higher plants. Academic Press, London.

Musick, J.T., and D.A. Dusek. 1980. Irrigated corn yield response to water. Trans. ASAE 23:92-98.

Norwood, C.A., and T.J. Dumler. 2002. Transition to dryland agriculture: Limited irrigated vs. dryland corn. Agron. J. 94:310-320.

Novoa, R., and R.S. Loomis. 1981. Nitrogen and plant production. Plant Soil 58:177-204.

Otegui, M.E., and F.H. Andrade. 2000. New relationships between light interception, ear growth and kernel set in maize. p. 89-102. In M.E. Westgate and K. Boote (ed.) Physiology and modeling kernel set in maize. CSSA Spec. Publ. 29. CSSA, Madison, WI.

Pandey, R.K., J.W. Maranville, and M.M. Chetima. 2000. Deficit irrigation and nitrogen effects on maize in a Sahelian environment: I. Grain yield and yield components. Agric. Water Manage. 46:1-13.

Raun, W.R., and G.V. Johnson. 1999. Improving nitrogen use efficiency for cereal production. Agron. J. 91:357-363.

Ritchie, S.W., J.J. Hanway, and G.O. Benson. 1997. How a corn plants develops. Spec. Publ. 48. Iowa State Univ. of Sci. and Technol. Coop. Ext. Serv., Ames.

Schussler, J.R., and M.E. Westgate. 1995. Assimilate flux determines kernel set at low water potential in maize. Crop Sci. 354:1074-1080.

Settimi, J.R., and J.W. Maranville. 1998. Carbon dioxide assimilation efficiency of maize leaves under nitrogen stress at different stages of plant development. Commun. Soil Sci. Plant Anal. 29:777-792.

Shaw, R.H. 1977. Climatic requirement. p. 315-341. In G.F. Sprague (ed.) Corn and corn improvement. Agron. Monogr. 18. ASA, CSSA, and SSSA, Madison, WI.

Sinclair, T.R., and T. Horie. 1989. Leaf nitrogen, photosynthesis, and crop radiation use efficiency: A review. Crop Sci. 29:90-98.

Tollenaar, M. 1989. Genetic improvement in grain yield of commercial maize hybrids grown in Ontario from 1959 to 1988. Crop Sci. 29: 119-124.

Tollenaar, M., L.M. Dwyer, and D.W. Stewart. 1992. Ear and kernel formation in maize hybrids representing three decades of grain yield improvement in Ontario. Crop Sci. 32:432-438.

Tollenaar, M., D.E. McCullough, and L.M. Dwyer. 1994. Physiological basis of the genetic improvement of corn. p. 183-236. In G.A. Slafer (ed.) Genetic improvement of field crops. Marcel Dekker, New York.

Tollenaar, M., and J. Wu. 1999. Yield improvement in temperate maize is attributable to greater stress tolerance. Crop Sci. 39:1597-1604. 
Troyer, A.F. 1999. Background of U.S. hybrid corn. Crop Sci. 39: 601-626.

Uhart, S.A., and F.H. Andrade. 1995a. Nitrogen deficiency in maize: I. Effects on crop growth, development, dry matter partitioning, and kernel set. Crop Sci. 35:1376-1383.

Uhart, S.A., and F.H. Andrade. 1995b. Nitrogen deficiency in maize: II. Carbon-nitrogen interaction effects on kernel number and grain yield. Crop Sci. 35:1384-1389.

USDA National Agricultural Statistics Service. 2003. Statistics of fer- tilizers and pesticides [Online]. Available at www.usda.gov/nass/ pubs/agr03/03_ch14.pdf (verified 20 Aug. 2004). USDA-NASS, Washington, DC.

Westgate, M.E., and J.S. Boyer. 1986. Reproduction at low silk and pollen water potentials in maize. Crop Sci. 26:951-956.

Wolfe, D.W., D.W. Henderson, T.C. Hsiao, and A. Alvino. 1988. Interactive water and nitrogen effects on senescence of maize: II. Photosynthetic decline and longevity of individual leaves. Agron. J. 80:865-870. 